\title{
SM Otolaryngology Profile of Patients with Hearing Loss from a Speech-Language Therapy Service between 2009 and 2015
}

\author{
Ana Cristina Guarinello*, Giselle Massi, Ana Paula Berberian, Rita Tonocchi, \\ Luciane Brasil, Monique Coelho Cassarotti and Adriano de Souza Pereira \\ Phonoaudiologist, University Tuiuti of Paraná (UTP), Brazil
}

Article Information

Received date: Sep 26, 2017

Accepted date: Oct 26, 2017

Published date: Nov 03, 2017

\section{${ }^{*}$ Corresponding author}

Ana Cristina Guarinello,

Phonoaudiologist, University Tuiuti of Paraná (UTP), Rua Alexandre Eduardo Klat, 66/2, Brazil, Tel: (041)33546346,

Email: ana.guarinello@utp.br

Distributed under Creative Commons CC-BY 4.0

Keywords Speech therapy; Health care; Diagnosis; Patients; Hearing loss

Article DOI 10.36876/smotol.1012

\section{OPEN ACCESS}

ISSN: 2574-2418

\section{Abstract}

Objective: To investigate the profile of deaf children who attended a teaching-clinic of Speech Language Therapy located in a city in the South of Brazil from 2009 to 2015.

Method: The study was conducted by collecting and analyzing the data found in patients with some degree of hearing loss profiles, in which the following variables were searched: age, gender, referral (who forwarded), origin, age of the diagnosis, hearing aids, complaints, Speech language therapy feedback.

Results: The most recurrent complaint in this clinic is hearing loss, the most frequent speech-language therapeutic feedback is the impairment in the development of the oral language due to hearing loss. As for the age of the diagnosis, 27 were diagnosed between 1 and 3 years old, 6 between 1 and 11 months old, 6 between 4 and 10 years old. Regarding the degree of the hearing loss, 15 present a profound hearing loss, 11 present moderate hearing loss, 7 present a mild hearing loss, and 6 present severe hearing loss. There was not sex prevalence, mean age was about 4 and a half years old, most patients are from Curitiba, and all of them were taken to the clinic by family members and referred by health professionals or by their school.

Conclusion: Many patients with oral language and hearing problems were found in this study, which demonstrates the need of prevention and health promotion actions in those areas.

\section{Introduction}

Language is an integral activity of getting to know the world by the child; therefore its construction is effected by means of the interaction among subjects. Through the language, a child acts upon the world and the others, and the adult is viewed as a mediator between the child and the world; adults act as interpreters [1], attributing sense and meanings to the child's language.

In a discursive perspective, language acquisition is a process actively experienced by engaged subjects in sociocultural activities, where adults are mediators between the child and the linguistic object. In the therapeutic process of children with hearing loss, language problems presented by those children do not only stem from the hearing loss, but also from the way they are introduced into the oral communication, as children who are active counterparts, develop into subjects by means of the language.

In spite of the importance of hearing for the language, it deems necessary to clear that language does not only entail hearing, discriminating, memorizing, but it is also subjects' (meta) linguistic task over the language, thus they make enunciation movements evidencing their word choices as well as the sociocognitive building of the meaning. Therefore, such movements affect language processing [2].

Moreover, early detection and use of hearing aids are fundamental for subjects to acquire the oral language. However, hearing losses have been diagnosed late in Brazil, which may cause irreversible damage to the linguistic, social, cognitive and emotional development of those children who suffer from such disorders [3]. The age of diagnosis and intervention is decisive for the oral linguistic development of children with hearing losses, since they may acquire the oral language as long as the loss is diagnosed early, and a speech-language therapeutic intervention begins [4].

One of the settings for speech-language therapeutic interventions are teaching clinics, which are usually supportive teaching and extension program units for the Speech-Language Therapy Course as well as integrating units of graduation learning projects nationwide. Thus, it is necessary to point out that the services provided in such clinics are supportive to integrate superior education and research development, besides being related to serve the population with teaching and learning extension practices [5].

It is also worth mentioning that those clinics also play a significant social role as they offer possibilities to access speech-language therapeutic services free-of charge or at a very low cost for 
the needy population [6]. Therefore, specific measures of prevention, diagnosis and treatment can be carried on to lessen the consequences of hearing losses, if the profile of such users is outlined [7]. Moreover, such measures may provide indicators which support planning, administration and assessment of health interventions related to a speech-language clinic [8]. These measures can also be an important tool to promote the improvement of such service, patient satisfaction and assess to the quality of service. Thus, the analysis of the patientes profile is essential for planning and coordinating activities in public health, as it contributes to the improvement in care by targeting patients, along with the development of more humane and welcoming speech therapy practices.

Besides it is a consensus that hearing loss is a major public health problem, because it affects the bio psycho social performance of the individual, interfering in educational, occupational and emotional issues. In the light of such considerations, our research question is what is the profile of patients with hearing loss from a Speech Language Therapy Service? The objective of this research is to investigate hearing-impaired children's profile, who are treated at a Speech-Language Therapy Clinic located in Curitiba from 2009 to 2015 from the following variables: age, gender, who forwarded, complaints regarding the initial interview, origin, age of hearing loss diagnosis, age of getting the hearing aid.

\section{Materials and Methods}

This is a descriptive study that was held in a teaching SpeechLanguage clinic located in the South of Brazil. The clinic has had a partnership with SUS (Unified Health System) since 2002 to perform in the program of Hearing Health, and is accredited as a high complexity service. It is considered a reference in this city and its Metropolitan Area with an interdisciplinary performance, enabling undergraduates to relate theory and practice, providing students with observation, screening, speech-language feedback, planning and speech-language therapeutic interventions. About 7,000 patients a year attend this clinic, which offers the following services: otorhinolaryngological consultation, tonal audiometry, impedance, audiometry, logoaudiometry, hearing-aid testing and fitting, newborn hearing screening, auditory steady-state response, otoacoustic emissions, auditory processing, balance screening, speech-language assessment and interventions for the voice, orofacial motricity, oral and written language areas [5].

Most children treated in this clinic are from the hearing aid sector, and many are referred to the hearing rehabilitation service in the same clinic after getting their hearing aid. Some choose for the rehabilitation in the clinic, but most of them choose an external support due to mobility difficulties, distance, etc.

Sample data were collected and analyzed by researchers from children with some degree of unilateral or bilateral hearing loss physical profiles, treated in this clinic from 2009 to 2015. Data were collected from June 2015 to December 2015. As this research does not relate users to their records, and their names were kept confidential, it should be pointed out that this research used data from the clinic records, do not have an Ethics Committee.

The research included files of children from 0 to 10 years old with hearing loss. Children with other disabilities were excluded from the data. The researchers looked at 100 files and 39 files were included for the analysis. All parents sign a free consent form so that their data can be used for the development o speech language research.

Data collected in the physical files by a speech language therapist researcher included: age, gender, who forwarded, complaints regarding the initial interview, origin, age of hearing loss diagnosis, age of getting the hearing aid. After collection, the data were entered into spread sheets and analyzed qualitatively by a content analysis.

\section{Results}

In this study, it was outlined the profile of patients with hearing loss treated in a speech-language therapeutic service of a university located in the South of Brazil, by means of data survey of their clinical records in the period between 2009 and 2015 .

As for the number of patients with some degree of hearing loss treated in this Teaching Clinic, 39 records were analyzed in this period.

Regarding these patients' age, the following data were found: age group from 1 to 4 years old - 20 subjects (51.28\%), age group from 5 to 10 years old -19 patients (48.71\%). Among them, 21 (53.84\%) were male, and 18 (46.15\%) were female.

In relation to who forwarded these children to this clinic, 8 patients $(20.51 \%)$ were forwarded by another Speech-Language Therapist, 7 (17.94\%) were forwarded by their School, 12 (30.76\%) were forwarded by the Screening Service of the university, 5 (12.82\%) via Hospital/Health Unit, 3 (7.6\%) by their Pediatrician, 2 (5.1\%) by their Ear-Nose-Throat Doctor, 1 (2.5\%) by the Center of Integral Care for the Cleft-Lip and Palate Patients (CAIF, in Portuguese), and $1(2.5 \%)$ by his/her own parents.

As for the origin of those patients, we could notice that 27 $(69.23 \%)$ are from a city located in the South of Brazil which is a State capital, 9 (23.07\%) are from this city Metropolitan Area, and 3 (7.6\%) are from other municipalities in the State.

The current research evidenced a prevalence of patients who live in the capital city, and $100 \%$ of those patients come to the clinic with their family members.

Data with the speech-language complaints regarding the initial interview are presented in table 1, the speech-language disorders are shown in table 2, with the age of the hearing loss diagnosis are presented in table 3 .

All the participant children were in kindergarten and in elementary school and all live with their parents. The responses about the degree of the hearing loss are in table 4 , and about the age they got the hearing aid can be seen in table 5 .

Table 1: Sample distribution by complaints $(n=39)$

\begin{tabular}{|c|c|c|}
\hline Most frequent complaints & N & $\%$ \\
\hline Hearing loss & 25 & 64.10 \\
\hline Does not speak & 6 & 15.38 \\
\hline Speech difficulties & 6 & 15.38 \\
\hline Difficulties in oral and written languages & 2 & 5.1 \\
\hline Total & 39 & 100 \\
\hline
\end{tabular}


Table 2: Sample distribution by speech-language disorders $(n=39)$.

\begin{tabular}{|c|c|c|}
\hline Speech-language Disorders & N & $\%$ \\
\hline Delay in the oral language development & 19 & 48.71 \\
\hline Hearing loss & 10 & 25.64 \\
\hline Speech difficulties & 7 & 17.94 \\
\hline Difficulties in reading and writing & 3 & 7.6 \\
\hline Total & 39 & 100 \\
\hline
\end{tabular}

Table 3: Sample distribution regarding age of diagnosis.

\begin{tabular}{|c|c|c|}
\hline Age of diagnosis & N & $\%$ \\
\hline 0 to 1 year old & 6 & 15.38 \\
\hline 1 to 3 years old & 27 & 69.23 \\
\hline 4 to 10 years old & 6 & 15.38 \\
\hline Total & 39 & 100 \\
\hline
\end{tabular}

Table 4: Sample distribution regarding degree of hearing loss $(n=39)$

\begin{tabular}{|c|c|c|}
\hline Degree of hearing loss & $\mathbf{N}$ & $\%$ \\
\hline Mild & 7 & 17.94 \\
\hline Moderate & 11 & 28.20 \\
\hline Severe & 6 & 15.38 \\
\hline Profound & 15 & 38.46 \\
\hline Total & 39 & 100 \\
\hline
\end{tabular}

Table 5: Sample distribution regarding age they got the hearing aid.

\begin{tabular}{|c|c|c|}
\hline Age they got the hearing aid & N & $\%$ \\
\hline Until 1 year old & 8 & 20.51 \\
\hline Between 1 and 2 years old & 15 & 38.46 \\
\hline Between 2 and 3 years old & 3 & 7.6 \\
\hline Between 3 and 4 years old & 3 & 7.6 \\
\hline Between 4 and 5 years old & 2 & 5.1 \\
\hline At 7 years old & 3 & 7.6 \\
\hline Do not wear a hearing aid & 5 & 12.8 \\
\hline Total & 39 & 100 \\
\hline
\end{tabular}

It was observed that 38 out of the 39 patients (97.43\%) began the speech-language therapeutic treatment in the same year of their clinical assessment, and only $1(2.5 \%)$ patient began the treatment in the following year.

\section{Discussion}

The Speech language therapy school-clinics has teaching and extension activities supporting units for the Speech language therapy courses, and the services that are offered at these places refer to public health services to the population. This study investigated the profile of deaf children, who attend a teaching-clinic of Speech Language Therapy located in a city in the South of Brazil from 2009 to 2015 and through this information's the demand can be analyzed and the service can be improved to better serve the children and their family.
This study presented a profile of early-age patients in speech therapy, most still in early childhood. Brazilian research also shows that the highest incidence of therapeutic sessions occurs in children up to 12 years of age $[8,9]$.

As for the users' profile, it was not observed in this study a significant gender difference. However, the greatest part of the national literature shows a higher pursuit of speech-language therapeutic treatment by male individuals [8,9]. Perhaps this sample shows higher gender parity because the main demanded complaint is related to hearing losses.

As for the age, this study shows that 1- to- 4 -year-old age group is prevalent in the clinic, probably because the greatest part of the sample had hearing loss diagnosed until 4 years of age. It should be pointed out that some patients had an early diagnosis, however this does not occur for a significant number of the Brazilian population, although such diagnosis is reached by means of the exam named Evoked Otoacoustic Emissions, mandatory nationwide since 2010 under Act n. 12.303 of August 2 $2^{\text {nd }}, 2010$.

Similar to other studies, the current research evidenced a prevalence of patients who live in the capital city [8] and its metropolitan area. Nonetheless, it could be observed that individuals who live in other cities are also treated in this teaching clinic, which possibly occurs due to the scarcity of speech-language therapeutic care in the public healthcare network in the municipalities they live in.

This study showed in a balanced way that most children were forwarded by health and education professionals, such as, speech-language therapists, teachers, pediatricians and otorhinolaryngologists. It was predictable since these professionals, in general, have direct contact with those children in appointments and follow up, thus having the possibility to observe any changes more carefully.

Literature also claims that most children from a speech-language pathology clinic are forwarded by health professionals [10], such as audiologists and pediatricians and by teachers $[11,12]$. This possibly occurs because they have better knowledge of speech-language therapists' interventions.

Table 1 shows that the most frequent complaints by the family who brings a child with hearing loss to a speech therapy clinic is the hearing loss, which is, according to the literature, the most frequent congenital hearing impairment among those usually screened ones in preventive health programs of any kind and degree of loss [13]. Besides, other parents also brought their children into the clinic because of the lack of speech, speech difficulties and some difficulties in the oral and written languages.

On the other hand, in table 2 the speech-language disorders referred by families could be seen, so the highest incidence was not exactly related to hearing impairment, but its consequences, such as delay in the oral language development due to the hearing loss, hearing aid or cochlear implant fitting, speech difficulties and reading and writing difficulties. This probably occurs due to the hearing impairment, which prevents a deaf child from acquiring the oral/auditory language, used by the greatest part of the community, without systematic therapy [14]. 
In our study, we observed that there is a relationship between age of the diagnosis and degree of hearing loss, as about $40 \%$ of the patients who had the diagnosis between 1 and 3 years of age presented profound hearing loss. Some literature studies clarify that despite the importance of early detection of hearing losses, they have been found late, which causes irreversible damage to children's linguistic, social, cognitive and emotional development $[15,16]$. Thus, the fact that those children with profound hearing loss having been diagnosed until three years of age, seems to be a positive factor in order to avoid a bigger damage in their development.

Another evidence was that children with hearing losses diagnosed after 4 years of age had mild and moderate hearing losses, which cause milder damage to language development, justifying, to a certain extent, the late finding of the impairment. It should also be clarified that the five children, showed in table 5, who did not wear hearing aid, suffered from unilateral hearing losses.

The fact of beginning treatment soon after the diagnosis enables good prognosis in the process of language acquisition, which allows better social and emotional integration of hearing-impaired children, making them capable of acting with and upon the language as early as possible [17].

Currently, in Brazil, the entrance for these patients to the speech language therapy clinic occurs in a Basic Health Unit. If this unit is well organized, it has the potential to meet the demands of the children with hearing losses and also their families. In addition, speech language therapists could act with these children as soon as possible helping them during their language acquisition process avoiding language difficulties consequences.

\section{Conclusion}

In this study, it was possible to investigate the profile of hearingimpaired children who are treated at a speech-language pathology clinic in the South of Brazil. The high rate of patients with a speech language assessed pathology in the areas of oral language and deafness, evidences the need for prevention and health promotion actions focused on aspects related to the oral communication and hearing impairment as soon as the hearing loss is detected. That is, the high number of patients who seek for treatment due to hearing losses and oral language difficulties enable to view the relevance to outline speech-language therapists' professional performance more accurately in institutions that refer patients to the clinic, elaborating proposals to work in Public Health.

Although our data sample was limitated, our next step will be to evaluate the family user's perceptions about the treatment Center where they were assisted, which we hope, will help to promote the improvement of the health system itself and, specifically, to make speech therapy a more humane practice.

\section{References}

1. Guarinello AC. O papel do outro na escrita de sujeitos surdos. São Paulo: Editora Plexus, 2007.

2. Santana AP. Surdez e Linguagem - Aspectos e implicações neurolinguísticas São Paulo: Plexus, 2007

3. Ribas A, Guarinello AC, Braga M, Cribari J, Filho OB, Cardoso SMS, et al Access to hearing health service in Curitiba-PR for the elderly with hearing loss and tinnitus. Int Tinnitus J. 2015; 19: 59-63.

4. Cóser MJS, Tochetto TM, Pedroso FS, Cóser PL, Gonçalves MS. Frequência do diagnóstico de surdez pré-lingual na ausência de indicadores de risco: a importância da triagem auditiva neonatal universal. Rev Temas desenvolv. 2011; 18: 66-69.

5. Girardelli GS, Guarinello AC, Berberian AP, Massi G, Marques JM. Atendimento em fonoaudiologia: estudo de uma clínica-escola na cidade de Curitiba-PR. Rev Ciênc Saúde. 2012; 34: 24-31.

6. Herzberg E. Reflexões sobre o processo de triagem de clientes a serem atendidos em clínicas-psicológicas-escola. Repensando a formação do psicólogo: da informação à descoberta. 1996; 1: 147-154

7. Pimentel MCR, Guimarães JATL, Flores NGC. Perfil epidemiológico de uma unidade pública de referência no tratamento em Fonoaudiologia. J Brás Fonoaud. 2006; 24: 43-50.

8. Costa RG, Souza LBRS. Perfil dos usuários e da demanda pelo serviço da clínica-escola de fonoaudiologia da UFBA. Ver Ci Méd Biol. 2009; 8: 53-59.

9. Mandrá PP, Diniz MV. Caracterização do perfil diagnóstico e fluxo de um ambulatório hospitalar na área de linguagem infantil. Rev Soc Bras Fonoaudiol. 2011; 16: 121-125.

10. Barros PML, Oliveira PN. Perfil dos pacientes atendidos no setor de fonoaudiologia de um serviço público em Recife-PE. Rev Cefac. 2010; 12 : 128-133.

11. Freire RM. Fonoaudiologia em saúde pública. Rev Saúde Pública. 1992; 26 : 179-184.

12. Gonçalves CGO, Lacerda CBF, Perotino S, Mugnaine AMM. Demanda pelos serviços de Fonoaudiologia no Município de Piracicaba:estudo comparativo entre a clínica-escola e o atendimento na prefeitura municipal. Rev Pró-Fono. 2000; 12: 61-66.

13. White RK, Vohr BR, Behrens TR. Universal newborn hearing screening using transient evoked otoacoustic emissions: results of the Rhode Island Learning Assessment Project. Semin Hear. 2003

14. Santana AP, Guarinello AC, Bergamo A. A clínica fonoaudiológica e a aquisição do português como segunda língua para surdos Distúrb Comum. 2013; 25: 440-451.

15. Guarinello AC, Claudio DP, Festa PSV, Paciornik R. Reflexões sobre as interações lingüísticas entre familiares ouvintes-filhos surdos. Tuiuti: Ciênc Cultura. 2013; 46: 151-168

16. Armigliato ME, Prado DGA, Melo TM, Martinez MANS, Lopes AC, Amantini RCB, et al. Avaliação de serviços de saúde auditiva sob a perspectiva do usuário: proposta de instrumento. Rev Soc Bras Fonoaudiol. 2010; 15: 32-39.

17. Santana AP. O processo de aquisição da linguagem: estudo comparativo de duas crianças usuárias de implante coclear. Distúrb Comum. 2005; 17 : 233-243. 